\title{
PENGARUH PENGGUNAAN MEDIA KARTU HURUF HIJAIYAH MENULIS PADA ANAK USIA DINI DI RA ATH-THOHA TASIKMALAYA
}

\author{
Fiani Nurafifah Ardin ${ }^{1}$, Dian Indihadi ${ }^{2}$, Taopik Rahman ${ }^{3}$ \\ ${ }^{1}$ Program Studi PGPAUD UPI Kampus Tasikmalaya \\ ${ }^{2}$ Program Studi PGSD UPI Kampus Tasikmalaya \\ ${ }^{3}$ Program Studi PGPAUD UPI Kampus Tasikmalaya
}

Email: fianinurafifahardin25@gmail.com

(Received: Mei 2020; Accepted: Mei 2020; Published: Juni 2020)

\begin{abstract}
The main problem in this research is how the ability of children to write hijaiyah letters before and after using hijaiyah card media, is there any constraints on using hijaiyah card media in writing hijaiyah letters, is there any influence of hijaiyah letter cards on children's ability to write hijaiyah letters. The purpose of this study was to determine the ability of children to write Hijaiyah letters before and after using hijaiyah letter media, to find out the constraints in using hijaiyah letter media in writing hijaiyah letters, the influence of hijaiyah letter media on children's ability to write hijaiyah letters. Letter cards are the use of a number of cards as a tool for learning to read by seeing and remembering the shape of letters. This research was conducted in RA Ath Thoha Cipedes Subdistrict, Panglayungan Village which aims to describe differences in the ability to write hijaiyyah letters in the control class and in the experimental class in children aged 5-6 years using hijaiyyah letter cards. Subjects in this study were children aged 5-6 years. This research uses a quantitative approach with the research method in Experimental Design. Data collection techniques used in this study were observation, interviews, documentation, questionnaires. The research findings show that from the results of data analysis the influence of the use of hijaiyyah letter media on early childhood writing skills in RA Ath Thoha Tasikmalaya.
\end{abstract}

Keywords: Use of Hijaiyyah Letter Card Media, Children, Aged 5-6 Years.

\begin{abstract}
ABSTRAK
Permasalahan pokok dalam penelitian ini adalah bagaimana kemampuan anak menulis huruf hijaiyah sebelum dan sesudah menggunakan media kartu huruf hijaiyah, adakah kendala penggunakan media kartu huruf hijaiyah dalam menulis huruf hijaiyah, adakah pengaruh media kartu huruf hijaiyah terhadap kemampuan anak menulis huruf hijaiyah. Adapun tujuan penelitian ini untuk mengetahui kemampuan anak menuli huruf hijaiyah sebelum dan sesudah menggunakan media kartu huruf hijaiyah, untuk mengetahui kendala dalam penggunaan media kartu hurufu hijaiyah dalam menulis huruf hijaiyah, adanya pengaruh media kartu huruf hijaiyah terhadap kemampuan anak menulis huruf hijaiyah. Kartu huruf adalah penggunaan sejumlah kartu sebagai alat bantu untuk belajar membaca dengan cara melihat dan mengingat bentuk huruf. Penelitian ini dilakuka di RA Ath Thoha Kecamatan Cipedes, Kelurahan Panglayungan yang bertujuan untuk mendeskripsikan perbedaan kemampuan menulis huruf hijaiyyah di kelas kontrol dan dikelas eksperimen pada anak usia 5-6 tahun dengan menggunakan kartu huruf hijaiyyah. Subjek dalam penelitian ini adalah anak usia 5-6 tahun. Penelitian ini menggunakan pendekatan metode penelitian kuantitatif eksperimen dengan rancangan eksperimen subjek tunggal (Single Subject Research) dengan menggunakan desain A-B-A. Teknik pengumpulan data yang digunakan dalam penelitian ini adalah observasi, wawancara, dokumentasi.
\end{abstract}

Kata Kunci: Penggunaan Media Kartu Huruf Hijaiyyah, Anak, Usia 5-6 Tahun . 


\section{PENDAHULUAN}

Pendidikan merupakan usaha sadar dan terencana untuk mewujudkan suasana belajar dan proses pembelajaran agar peserta didik secara aktif mengembangkan potensi dirinya untuk memiliki kekuatan spiritual keagamaan, pengendlian diri, kepribadian, kecerdasan, akhlak mulia serta keterampilan yang diperlukan dirinya, masyarakat, bangsa dan Negara (UU SISDIKNAS No. 20 2003). Maka dapat dikatakan bahwa anak memiliki hak untuk mendapatkan pendidikan dari sejak ia dilahirkan. Pendidikan yang diberikan kepada anak dari sejak lahir hingga usia 6 tahun adalah Pendidikan Anak Usia Dini (PAUD). Menurut Undang-Undang Nomor 20 Tahun 2003 Pasal 1 ayat (14) PAUD adalah suatu upaya pembinaan yang dilakukan melalui pemberian rangsangan pendidikan kepada anak sejak lahir sampai dengan berusia enam tahun. PAUD bertujuan untuk membantu pertumbuhan dan perkembangan jasmani dan rohani anak agar memiliki kesiapan dalam memasuki pendidikan lebih lanjut.

Pendidikan Nasional berfungsi mengembangkan kemampuan dan membentuk watak serta peradaban bangsa yang bermartabat dalam rangka mencerdaskan kehidupan bangsa, bertujuan untuk berkembangnya potensi peserta didik agar menjadi manusia yang beriman dan bertaqwa kepada Tuhan Yang Maha Esa, berakhlak mulia, sehat, berilmu, cakap, kreatif, mandiri, dan menjadi warga negara yang demokratis serta bertanggung jawab, yang sesuai dengan apa yang tertuang dalam UU No 20 tahun 2003. Tujuan Kelembagaan sebagaimana tercantum dalam Peraturan Menteri Agama No 13 Tahun 2012 yakni melaksanakan pelayanan umum dan bimbingan di Bidang Pendidikan Agama dan Keagamaan Islam.

Belajar menurut Hamalik (2001:27) merupakan suatu proses, suatu kegiatan, dan bukan suatu hasil atau tujuan. Belajar bukan hanya mengingat, akan tetapi lebih luas dari itu, yaitu mengalami. Hasil belajar bukan suatu penguasaan hasil latihan melainkan pengubahan kelakuan. belajar bukan suatu tujuan tetapi merupakan suatu proses untuk mencapai tujuan

RA Ath Thoha adalah Satuan Pendidikan Anak Usia Dini jalur Formal yang menyelenggarakan program pendidikan dengan ke khasan Agama Islam bagi anak usia 4 Tahun sampai 6 Tahun, yang mempunyai kurikulum berisi program program pengembangan nilai agama dan moral, motorik, kognitif, Bahasa, social-emosional dan seni.

\begin{tabular}{lcrr}
\multicolumn{1}{c}{ Piaget } & dalam & Karwono & $(2010: 85)$ \\
menyatakan & bahwa belajar merupakan \\
pengolahan & informasi & dalam rangka \\
membangun & sendiri & pengetahuannya. \\
Keberhasilan & individu dalam mengolah
\end{tabular} informasi merujuk pada kesiapan dan kematangan dalam perkembangan kognitifnya. Berdasarkan pendapat Piaget, dalam proses belajar yang terpenting adalah bagaimana siswa atau si belajar mampu mengembangkan serta mengolah sendiri pengetahuan atau informasi yang diterimanya, sehingga kemampuan yang akan diterimanya akan jauh lebih matang dan lebih berkembang terutama dalam aspek kognitif.

Menurut Gagne dalam Suprijono (2012:2) bahwa belajar adalah perubahan disposisi atau kemampuan yang dicapai seseorang melalui aktivitas. Perubahan disposisi tersebut bukan diperoleh langsung dari proses pertumbuhan seseorang secara alamiah. Belajar menurutnya adalah suatu yang diperoleh individu melalui penalaran sendiri berdasarkan aktivitas yang dilakukannya.

Berdasarkan pendapat ahli-ahli di atas, maka dapat disimpulkan bahwa belajar merupakan suatu proses yang dialami oleh setiap individu meliputi perubahan tingkah laku dari tidak tahu menjadi tahu. Dengan belajar setiap individu akan mendapatkan pengetahuan dan wawasan yang lebih luas dari sebelumnya serta mampu mengkonstruk sendiri pengetahuan, informasi dan 
pengalaman baik yang didapat maupun yang dialami dan dipengaruhi oleh lingkungan.

Terdapat beberapa prinsip-prinsip
belajar Menurut Dimyati dan Mudjiono
(2009:42) prinsip-prinsip belajar ada tujuh
prinsip, yaitu:

1) Perhatian dan motivasi

Perhatian mempunyai peranan yang penting dalam kegiatan belajar. Dari kajian teori belajar pengolahan informasi terungkap bahwa tanpa adanya perhatian tak mungkin terjadi belajar (Gage dan Berliner, 1984:335). Perhatian terhadap pelajaran akan timbul pada siswa apabila bahan pelajaran sesuai dengan kebutuhannya. Di samping perhatian, motivasi mempunyai peranan pentin dalam kegiatan belajar. Motivasi adalah tenaga yang menggerakkan dan mengarahkan aktivitas seseorang.

2) Keaktifan

Dalam setiap proses belajar, siswa selalu menampakkan keaktifan. Keaktifan itu beraneka ragam bentuknya. Mulai dari kegiatan fisik yang mudah kita amati dampai kegiatan psikis yang sulit diamati. Kegiatan fisik bisa berupa membaca, mendengar, menulis, berlatih keterampilan-keterampilan dan sebagainya. Contoh kegiatan psikis, misalnya menggunakan khasanah pengetahuan yang dimiliki dalam memecahkan masalah yang dihadapi, membandingkan satu konsep dengan yang lain, meyimpulkan hasil percobaan dan lainnya.

3) Keterlibatan langsung/berpengalaman

Keterlibatan siswa di dalam belajar jangan diartikan keterlibatan fisik semata, namun lebih dari itu terutama adalah keterlibatan mental emosional, keterlibatan dengan kognitif dalam pencapaian dan perolehan pengetahuan, dalam penghayatan dan internalisasi nilainilai dalam pembentukan sikap dan nilai, dan juga mengadakan latihanlatihan dalam pembentukan keterampilan.

4) Pengulangan

Prinsip pengulangan penting dilakukan, karena pengulangan dapat melatih daya-daya jiwa, membentuk respons yang benar dan membentuk kebiasaan-kebiasaan.

5) Tantangan

Dalam situasi belajar siswa menghadapi suatu tujuan yang ingin dicapai, tetapi selalu terdapat hambatan yaitu mempelajari bahan belajar, maka timbulah motif untuk mengatasi hambatan itu yaitu dengan mempelajari bahan belajar tersebut. Apabila hambaan itu telah diatasi, artinya tujuan belajar telah tercapai, maka ia akan masuk dalam medan baru dan tujuan baru, demikian seterusnya. Agar pada anak timbul motif yang kuat untuk mengatasi hambatan dengan baik maka bahan belajar haruslah menantang. Tantangan yang dihadapi dalam bahan belajar membuat siswa bergairah untuk mengatasinya.

6) Balikan dan penguatan

Prinsip belajar yang berkaitan dengan balikan dan penguatan. Siswa akan belajar lebih bersemangat apabila mengetahui dan mendapatkan hasil yang baik. Hasil yang baik merupakan balikan yang menyenangkan dan berpengaruh baik bagi usaha belajar selanjutnya.

7) Perbedaan individual

Siswa merupakan individual yang unik artinya tidak ada dua orang siswa yang sama persis, tiap siswa memiliki perbedaan satu dengan orang lain. Perbedaan itu terdapat pada 
karakteristik psikis, kepribadian, dan sifat-sifatnya. Perbedaan individual tersebut akan berpengaruh pada cara dan prestasi belajar siswa.

Berdasarkan pendapat ahli-ahli di atas maka dapat disimpulkan bahwa prinsip dalam belajar itu ada beberapa macam yang semuanya bertujuan menumbukan semangat kepada siswa untuk giat untuk belajar sehingga dalam proses pembelajaran guru berhasil dan siswa dapat mendapatkan hasil belajar sesuai tujuan belajar.

Adapun ciri-ciri Menurut Djamarah (2011:15). Ciri-ciri belajar ada enam, yaitu sebagai berikut:

1. Perubahan yang terjadi secara sadar

2. Perubahan dalam belajar bersifat fungsional

3. Perubahan dalam belajar bersifat positif dan aktif

4. Perubahan dalam belajar bukan bersifat sementara

5. Perubahan dalam belajar bertujuan dan terarah

6. Perubahan mencakup seluruh aspek.

Ada beberapa perubahan tertentu yang dimaksudkan kedalam ciri-ciri belajar. Menurut Dimyanti dan Mudjiono (2009: 15) beberapa ciri-ciri belajar yaitu:

a. Untuk membentuk anak didik dalam suatu perkembangan tertentu.

b. Didesain untuk mencapai tujuan yang telah ditetapkan agar dapat mencapai tujuan secara optimal.

c. Kegiatan belajar mengajar ditandai dengan satu penggarapan materi yang khusus.

d. Ditandai dengan aktivitas anak didik.

e. Dalam kegiatan belajar mengajar, guru berperan sebagai pembimbing.

f. Dalam kegiatan belajar mengajar membutuhkan disiplin.

g. Ada batas waktu.

h. Evaluasi.
Berdasarkan pendapat di atas dapat disimpulkan bahwa ciri-ciri belajar itu meliputi banyak hal diantaranya yaitu perubahan belajar secara sadar, fungsional, optimal, penggarapan mataeri yang khusus, ditandai dengan aktivitas anak didik, memiliki tujuan yang terarah, mencakup seluruh aspek, ada batas waktu dan evaluasi.

Terdapat beberapa pengertian pembelajaran yang dikemukakan oleh para ahli seperti Alvin W. Howard dalam Daryanto (2010: 162) memberikan defenisi pembelajaran sebagai berikut: "Pembelajaran adalah suatu aktivitas untuk mencoba menolong, membimbing seseorang untuk mendapatkan, mengubah atau mengembangkan skill, attitude, ideal (cita-cita) aprprections (penghargaan) dan knowledge".

Pendapat Waini Rasidin dalam Daryanto (2010: 164) pembelajaran yang dipentingkan ialah adanya partisipasi guru dan siswa satu sama lain, guru merupakan koordinator yang melakukan aktivitas dalam interaksi sedemikian rupa sehingga siswa belajar seperti yang kita harapkan, guru hanya menyusun dan mengatur situasi belajar dan bukan menentukan proses belajar

Untuk meningkatkan kemampuan anak mengenalkan huruf hijaiyyah peneliti mencoba menggunakan strategi pembelajaran melalui media kartu huruf hijaiyah yang begitu disenangi oleh anak. Hal ini dapat menarik minat dan semangat belajar anak mengenal huruf-huruf hijaiyah dan menulis huruf hijaiyah, Anak menjadi terkesan dan semangat dalam belajar. Dengan demikian, anak mudah mengingat setiap huruf-huruf hijaiyah yang dipelajari. Diharapkan setelah semua huruf-huruf dikenalkan, memudahkan anak untuk menulis. Berdasarkan cara diatas, maka penulis berpendapat bahwa menulis huruf hijaiyyah sangatlah penting bagi perkembangan anak, maka peneliti merasa perlu mengadakan penelitian untuk 
mengetahui "Pengaruh Penggunaan Media Kartu Huruf Hijaiyyah menulis pada Anak Usia Dini di RA Ath Thoha”.

Moeleong (2002:49) juga mengatakan bahwa kemampuan adalah: Kepercayaan seseorang kepada diri seseorang akan dapat menyelesaikan pekerjaan dengan sukses. Berdasarkan definisi tersebut kemampuan diartikan berupa pengetahuan, penguasaan ilmu, keterampilan yang dimiliki seorang untuk melakukan kegiatan atau tugas yang diembannya. Kemampuan (ability), Sering disamakan dengan bakat (aptitude). William dan micahel (dalam suryabrata,2004:160). Menjelaskan bahwa bakat merupakan kemampuan individu untuk melakukan suatu tugas yang 337 tergantung sedikit banyak dari latihan, sedangkan Bingham (dalam suryabrata, 2004 : 161) menitik beratkan pada kemampuan individu setelah individu tersebut mendapat latihan-latihan.

Kartu huruf hijaiyyah adalah alat peraga yang digunakan untuk proses belajar mengajar agar dapat mempermudah atau menyampaikan materi pembelajaran. Huruf huruf yang digunakan sebagai dasar pembelajaran membaca Al-Qur'an. Dalam bahasa Indonesia, Huruf hijaiyyah sama dengan huruf-huruf alphabet yang menjadi dasar pengenalan bagi mereka yang sedang belajar membaca. Anak kesulitan dalam belajar menghafal huruf hijaiyyah kurang maksimal.

Masa anak usia dini adalah masa anak dalam mengeksplorasi, mengidentifikasi, meniru, dan masa bermain. Masa bermain anak adalah kegiatan yang dilakukan atas dasar suatu kesenangan dan tanpa mempertimbangkan hasil akhir, kegiatan tersebut dilakukan secara sukarela, tanpa paksaan atau tekanan dari pihak luar (Musfiroh, 2016,hlm.44).

\section{TINJAUAN PUSTAKA}

Berdasarkan Undang-undang Nomor 20 Tahun 2003 tentangh Sistem Pendidikan Nasional yang berkaitan dengan Pendidikan Anak Usia Dini yang tertulois pada pasal 28 ayat 1 yang isinya "Pendidikan Anak Usia Dini di selenggarakan bagi anak sejak lahir sampai enam tahun dan bukan merupakan prasyarat untuk mengikuti pendidikan dasar". Selanjutnya di tegaskan pada Bab I pasal 1 ayat 14 ditegaskan bahwa Pendidikan Anak Usia Dini adalah suatu upaya pembinaan yang ditujukan kepada anak sejak lahir sampai dengan usia enam tahun yang dilakukan melalui pemberian rangsangan pendidikan untuk membantu pertumbuhan dan perkembangan jasmani dan rohani agar anak memiliki kesiapan dalam memasuki pendidikan lebih lanjut.

Kata media berasal dari bahasa latin dan merupakan bentuk jamak dari kata medium. Yang secara harafiah berarti perantara atau pengantar.Menurut Azhar Arsyad (2002:3) menyatakan bahwa:"Guru Buku teks, dan lingkungan sekolah merupakan media secara lebih khusus, pengertian media dalam proses belajar mengajar cenderung diartikan sebagai alat-alat grafis, photografis, atau elektonis untuk menangkap, memproses, dan menyusun kembali informasi visual atau verbal. Pesanpesan yang disampaikan oleh guru kepada anak melalui suatu media dengan menggunakan prosedur kegiatan belajar tertentuyang disebut metode"

Media Kartu Huruf termasuk media visual yang terbuat dari kertas dan terdapat unsur huruf-huruf abjad baik Latin atau Arab. Pelaksanaan permainan dengan menggunakan media Kartu Huruf digunakan untuk mengetahui kemampuan menulis awal pada anak. Sehingga anak akan tertarik dan termotivasi untuk mengikuti kegiatan belajar. Berdasarkan uraian tersebut maka kerangka berfikir dalam penelitian ini dapat dilihat pada gambar dibawah ini. 
Selanjutnya dalam buku garis-garis besar program media pendidikan Departemen pendidikan dan kebudayaan (1997/1998:1-2)menyatakan bahwa:

Pengertian media pendidikan dalam arti umum ialah segala jenis sarana pendidikan yang digunakan sebagai perantara dalam proses belajar mengajar untuk meningkatkan efektivitas dan efisien. Sedangkan Pengertian Media Pendidikan dalam arti khusus ialah segala jenis sarana pendidikan yang digunakan sebagai perantara dengan menggunakan alat penampilan dalam proses belajar mengajar untuk meningkatkan efektivitas dan efisien dalam pencapaian tujuan pendidikan.

\section{Selanjutnya Cucu Eliyawati} (2005:106) mengemukakan beberapa pengertian:

1. Media pendidikan merupakan wahana dari pesan yang oleh sumber pesan (guru) ingin diteruskan kepada penerima pesan.

2. Pesan yang disampaikan adalah isi kegiatan belajar dalam bentuk kegiatan yang disesuaikan dengan tema atau topic kegiatan.

3. Tujuan yang ingin dicapai adalah terjadinya proses belajar pada diri anak

Kartu huruf adalah penggunaan sejumlah kartu sebagai alat bantu untuk belajar membaca dengan cara melihat dan mengingat bentuk huruf dan gambar yang disertai tulisan dari makna gambar pada kartu (Maimunah Hasan, 2009: 65).

Menurut Kamus Besar Bahasa Indonesia (1997), Menulis adalah membuat huruf (angka dan lain sebagainya), yang dibuat (digurat dan lain sebagainya), dengan pena (pensil, cat, dan lain sebagainya). Jadi menulis itu berarti menorehkan huruf atau angka dengan pensil atau cat ke atas kertas atau benda lainnya yang memungkinkan dapat terbaca secara jelas dan mengandung makna tertentu. Jadi menulis bukan sekedar menggambar atau memindahkan atau juga meniru tetapi menulis juga mengandung arti atau makna atau pesan yang dibawa oleh penulis tersebut.

Sejarah pendirian Sekolah ini, RA Ath Thoha berkedudukan di jalan Hanura Sukamaju I RT 03 RW 09 Kelurahan Panglayungan Kecamatan Cipedes Kota Tasikmalaya, Yang berada berbatasan di sebelah Timur Kp. Sukamaju II RW 08 sebelah Utara Sukamaju Kaler RW 16, sebelah Barat Kp. Cikiara RW 11 dan sebelah Selatan daerah Sungai yang berbatasan dengan Cieunteung Kec. Cihideung.

RA Ath-Thoha Tasikmalaya berdiri atas inisiatif dari bapak Drs. Tedih Sukmadin yang didasarkan pada hasil analisa kebutuhan masyarakat terhadap pendidikan Islam yang semakin tinggi serta pemanfaatan sarana wakaf agar lebih berfungsi secara efektif Karena proses pendirian ini perlu didukung dengan tidak hanya pada fasilitas serta tenaga pendidik, akan tetapi juga harus memiliki Yayasan sebagai legalisasi secara kelembagaan yang akan menopang terhadap keberlangsungan sebuah lembaga pendidikan formal berbasis Islami. Pada tahun 2006 kami mulai mengajukan pendirian pendidikan formal RA ini namun belum mendapatkan hasil yang memuaskan, terkait dengan adanya rotasi para penjabat di lingkungan kementerian agama. Akhirnya pada tahun 2009 kami mengukuhkan untuk melaksanakan pendidikan formal RA Ath Thoha walaupun belum mendapatkan ijin operasional.

Pada tahun 2010 kami kembali mengajukan permohonan ijin operasional, alhamdulillah mendapat perhatian yang cukup baik. Dan pada tahun 2011 ijin opeprasional pun telah diterbitkan. 


\section{METODE PENELITIAN}

penelitian Pengaruh Penggunaan

Media Kartu Huruf Hijaiyah Terhadap Keterampilan Menulis Anak Usia Dini di RA Ath-Thoha Tasikmalaya. peneliti menggunakan metode penelitian kuantitatif eksperimen dengan rancangan eksperimen subjek tunggal (Single Subject Research) dengan menggunakan desain A-B-A. Menurut Krathwohl, (1997:7) dalam Syaodih (2006:57) mengemukakan bahwa "penelitian eksperimen merupakan penelitian yang bersifat validation atau menguji, yaitu menguji pengaruh satu atau lebih variabel terhadap variabel lain". Datadata yang didapat dari penelitian kuantitatif berupa angka-angka dan analisis dalam menggunakan statistik.

Single Subject Research (SSR) atau lebih dikenal dengan penelitian subjek tunggal, yakni suatu metode penelitian eksperimen yang dilaksanakan pada subjek tunggal atau lebih dengan tujuan untuk mengetahui besarnya pengaruh dari perlakuan atau intervensi yang diberikan secara berulangulang terhadap perilaku yang ingin dirubah dalam waktu tertentu, sedangkan desain tunggal yang dipakai adalah pola A-B-A, yang terdiri dari tahapan kondisi A-1 (baseline-1), B (perlakuan), A-2 (baseline-2).

Desain eksperimen memiliki beberapa jenis dan jenis desain eksperimen yang dipakai dalam penelitian ini adalah desain eskperimen Single Case yang merupakan metode evaluasi yang bisa dimanfaatkan untuk menguji secara ketat keberhasilan sebuah intervensi atau tritmen terhadap kasus tertentu bisa berupa orang, sekolah atau komunitas serta untuk memberikan evidensi atau bukti tentang kefektivan sebuah intervensi dengan menggunakan sampel berukuran relatif kecil (Ryan \& Filene, 2012: 1).

\section{TEMUAN}

Wawancara, didefiniskan sebagai kegiatan tanya jawab antara pewawancara dengan narasumber untuk mendapatkan informasi sesuai dengan topik pembahasan. Oleh karena itu, wawancara diperlukan dalam pengumpulan data. Menurut Sugiyono (2016, hlm.137) bahwa "wawancara digunakan sebagai teknik pengumpulan data apabila peneliti ingin melakukan studi pendahuluan untuk menemukan permasalahan penelitian, dan juga apabila peneliti ingin mengetahui halhal dari responden agar penelitian lebih mendalam dan jumlah respondennya sedikit/kecil". Teknik ini sengaja akan digunakan oleh peneliti untuk memperoleh data yang lebih akurat terhadap kefektifan metode kartu terhadap menulis huruf hijaiyyah pada anak. Dan peneliti telah mewawancara guru terhadap anak yang akan diteliti.

Sebelum melakukan penelitian ,peneliti mewawancara guru dari RA Ath Thoha untuk meminta izin akan mengadakan penelitian single case dengan hanya mengambil simple saja dan menentukan subjek yang akan di teliti oleh peneliti.

Selanjutnya Sebelum peneliti melakukan penelitian kegiatan ini, peneliti meminta izin terlebih dahulu pada aparat setempat RW dan kelurahan. Disini peneliti melaksakanakan penelitian eksperimen single case ini karna adanya pandemi Covid-19, karena dalam keterangan dan panduan Covid ini tidak boleh melakukan perkumpulan atau mengadakan kumpulan apalagi bersama anak usia dini karna mudahnya terjangkitnya atau tersebarnya virus virus pada anak.

Aspek yang diobservasi pada anak usia 5-6 tahun. Observasi dilakukan dengan mengamati kegiatan anak sebelum dan sesudah mendapatkan perlakuan (treatment) menggunakan media kartu Huruf Hijaiyah berdasarkan dengan instrumen yang telah diuji validasi dan relibilitasnya. Setelah hasil data diperoleh melalui instrumen penelitian kemudian diolah dan dianalisis untuk mendapatkan hasil dan dipergunakan untuk menjawab pertanyaan dan menguji kebenaran hipotesis. 
Dokumentasi, merupakan suatu teknik untuk mengumpulkan data dengan menghimpun dan menganalisis dokumen, baik dokumen tertulis, gambar, maupun elektronik. Dokumentasi juga digunakan untuk mencari data dan melengkapi data. Dalam penelitian ini, dokumentasi yang digunakan berupa gambar dan tertulis kegiatan menulis anak dan hasil belajar anak usia 5-6 tahun di Tasikmalaya yang merupakan data pelengkap informasi atau bukti bahwa kegiatan yang telah direncanakan benar-benar telah dilaksanakan.

\section{KESIMPULAN}

Desain eksperimen kasus tunggal (single-case experimental design) diperlukan dan harus melakukan pengukuran keadaan awal sebagai fungsi prates. Keadaan awal (baseline) merupakan pengukuran (beberapa) aspek dari perilaku subjek selama beberapa waktu sebelum perlakuan. Rentang waktu pengukuran untuk menetapkan baseline ini disebut fase keadaan awal (baseline phase). Fase keadaan awal ini memiliki fungsi deskriptif dan fungsi prediktif. Fungsi deskriptif (descriptive function) adalah fungsi untuk menggambarkan keberadaan level performansi (keadaan perilaku) subjek yang dieksperimen secara alamiah, tanpa adanya suatu perlakuan. Sedangkan fungsi prediktif atau disebut juga dengan fungsi projektif adalah fungsi untuk meramalkan level performansi (perilaku) subjek jika tidak ada intervensi. Baseline berfungsi sebagai landasan pembanding untuk menilai keefektifan suatu perlakuan.(Sunanto:2005).

Dengan teknik pengumpulan datanya yaitu dengan observasi, wawancara, dokumentasi. Kegiatan penelitian tentunya memerlukan tempat penelitian yang akan dijadikan sebagai latar untuk memperoleh data yang diperlukan guna mendukung tercapainya tujuan penelitian. Penelitian ini dilaksanakan di lingkungan sekitar rumah yaitu RT 02 RW 09 Kel.Panglayungan, Kec. Cipedes, Kota Tasikmalaya. Penelitian ini dilaksanakan di lingkungan sekitar rumah dengan mengambil sampel anak yang sekolah di RA Ath Thoha dengan jarak rumah yang berdekatan.

Kendalanya tidak semua anak dapat mampu menulis atau masih malu-malu serta masih dibantu oleh peneliti sehingga banyak memerlukan perhatian peneliti.karena anak masih tahap belajar untuk menulis huruf hijaiyah.

\section{SARAN}

Bagi peneliti anak usia dini ini agar diberi motivasi lagi untuk melakukan kegiatan belajarnya.

Peneliti menggunakan media krtu huruf hijaiyah ini untuk melatih anak mengenal huruf hijaiyah agar bisa menulis huruf hijaiyah.

\section{DAFTAR PUSTAKA}

Arsyad,Azhar.(2002).Media

Pembelajaran,Jakarta : PT Raja Grafindo Persada.

Daryanto, 2010. Belajar dan Mengajar.Yrama Widya. Bandung.

Dimyati dan Mudjiono. 2009. Belajar dan Pembelajaran.Rineka Cipta: Jakarta.

Djamarah, Syaifu, Bahri. 2002. Rahasisa Sukses Belajar.Rineka Cipta. Jakarta. . 2011. Psikologi Belajar. PT.

Rineka Cipta. Jakarta

Eliyawanti,Cucu.(2005).Pemilihan dan

Pengembangan Sumber Belajar Untuk

Anak Usia Dini. Jakarta : Depdiknas.

Hamalik, O. 2001. Metode Mengajar dan Kesulitan Belajar. Transito. Bandung.

Karwono dan Heni Mularsih 2010. Belajar dan Pembelajaran serta Pemenfaatan Sumber Belajar. Cerdas Jaya: Ciputat. 
Moeleong.(2002). Metodologi Penelitian

Kualitatif. Bandung : Remaja

Rosdakarya

Ryan, K., \& Filene, J. (2012). Selecting appropriate single case designs for evaluating MIECHV funden home visiting programs. Single Case Design Brief, March, 1-9.

Sugiyono.2006.Metode Penelitian Kuantitatif, Kualitatif dan R \& D.Bandung:Alfabeta.

Suprijono, Agus. 2012. Cooperative Learning. Pustaka Pelajar: Yogyakarta.

Undang-Undang Republik Indonesia Nomor 20 Tahun 2003 tentang Sisdiknas. Kemendikbud: Jakarta. 